\title{
De preliminaire \\ ontvankelijkheidsbeslissing onder de WAMCA: hoe 'inhoudelijk' mag de voorfase zijn?
}

\author{
$P i m W_{i s s i n k}^{*}$
}

\section{Inleiding en probleemstelling}

Vorig jaar introduceerde de langverwachte Wet afwikkeling massaschade in collectieve actie (WAMCA) de mogelijkheid van een collectieve schadevergoedingsactie in ons recht. Dat ging bovendien gepaard met een nieuw procedureel kader voor de collectieve rechtsgang in de vorm van titel $14 \mathrm{a}$ Rv. Een aspect van de nieuwe regeling dat in eerste instantie wellicht minder in het oog springt, is de uitdrukkelijke onderverdeling van de procedure in een preliminaire ontvankelijkheidsfase en een inhoudelijke fase. ${ }^{1}$

Art. $1018 \mathrm{c}$ lid $5 \mathrm{Rv}$ bepaalt thans dat inhoudelijke behandeling van de collectieve rechtsvordering slechts plaatsvindt indien en nadat de rechter een (positieve) beslissing heeft genomen over de aldaar genoemde voorvragen. ${ }^{2}$ Ten eerste (onder a) dient de rechter te toetsen of de opgekomen belangenorganisatie voldoet aan de ontvankelijkheidseisen van art. 3:305a lid $1 \mathrm{t} / \mathrm{m} 3 \mathrm{BW}$. Ten tweede (onder b) moet de belangenorganisatie voldoende aannemelijk hebben gemaakt dat het voeren van deze collectieve vordering efficiënter en effectiever is dan het instellen van een individuele vordering. Ten derde (onder c) moet niet summierlijk van de ondeugdelijkheid van de collectieve vordering blijken op het moment waarop het geding aanhangig is gemaakt. De rechter toetst een en ander zo nodig ambtshalve. ${ }^{3}$ De wet bepaalt voorts dat verweerders het voeren van een inhoudelijk verweer tegen de collectieve actie kunnen uitstellen tot na een positieve ontvan-

Mr. P.G.J. Wissink is promovendus en docent burgerlijk recht aan de Rijksuniversiteit Groningen.

Dit artikel is voor publicatie an een double blind peer review onderworpen.

1. Zie ook C.J.M. Klaassen, 'De Wet collectieve afwikkeling massaschade in collectieve actie: eindelijk werkelijkheid, nu nog gaan werken ...', $T C R$ 2019, afl. 4, p. 150; W.H. van Boom, 'WCA $\rightarrow$ WCAM $\rightarrow$ WAMCA', $T v C 2019$, afl. 4, p. 155-158.

2. Hoewel het de rechter voorheen vrijstond om bij de aanvang van een collectieve actie een deelvonnis over de ontvankelijkheid te wijzen, was hij daartoe onder de oude regeling niet verplicht. Zie bijv. Rb. Amsterdam 20 november 2019, ECLI:NL:RBAMS:2019:8741 (Volkswagen Car Claim).

3. Kamerstukken II 2016/17, 34608, nr. 3, p. 39. kelijkheidsbeslissing (art. 1018c lid 5, laatste volzin, jo. art. $1018 \mathrm{~g} \mathrm{Rv}$ ).

Het Nederlandse recht loopt daarmee in de pas met wat in veel Anglo-Amerikaanse class action-regimes gangbaar is. Daar gaat aan de behandeling van een class action steevast certification vooraf: de preliminaire beslissing waarbij de rechter toetst of de zaak geschikt is om als collectieve procedure voortgang te vinden. ${ }^{4}$ De gedachte achter een dergelijke tweesplitsing is er een van proceseconomie. Door in een vroeg stadium ongeschikte zaken weg te filteren kan een tijdrovende en kostbare, maar uiteindelijk vruchteloze inhoudelijke behandeling worden vermeden. Ook de WAMCA onderscheidt om die reden de ontvankelijkheidsfase van de inhoudelijke behandeling. $^{5}$

De vraag is wel in hoeverre de ontvankelijkheidsbeoordeling in de eerste fase van de procedure los kan worden gezien van de inhoudelijke beoordeling die in de tweede fase zal volgen. Een aantal elementen van de ontvankelijkheidstoets is namelijk nauw verweven met de inhoudelijke beoordeling van de vordering. Ik doel op de eis van 'gelijksoortige belangen' (art. 3:305a lid 1 BW jo. art. 1018c lid 5 onder a en b Rv) en de nieuwe 'summierlijk ondeugdelijk'-toets (art. 1018c lid 5 onder c Rv). Zoals verderop zal blijken, vereist een beslissing ten aanzien van deze 'inhoudelijke' elementen in de ontvankelijkheidstoets in wezen dat de rechter vooruitblikt op het debat en de beoordeling in de inhoudelijke fase van het geding. ${ }^{6}$ In zoverre vervaagt de scherpe procedurele tweedeling die de WAMCA presenteert en is er een zekere spanning met het voorschrift van art. $1018 \mathrm{c}$ lid $5 \mathrm{Rv}$.

De centrale vraag in dit artikel is hoe de regel van art. $1018 \mathrm{c}$ lid $5 \mathrm{Rv}$ moet worden opgevat in verhouding tot de 'inhoudelijke' elementen van de ontvankelijkheidstoets en hoe de rechter het beste met die aspecten van de ontvankelijkheidstoets kan omgaan. Aan die vraagstelling ligt de gedachte

\footnotetext{
4. R. Mulheron, The class action in common law legal systems. A comparative perspective, Oxford: Hart Publishing 2004, p. 23-24.

5. Kamerstukken II 2016/17, 34608, nr. 3, p. 39.

6. C.M.D.S. Pavillon, 'Leent het materiële privaatrecht zich voor de afwikkeling van massaschade?', RMThemis 2019, p. 165 en 174.
} 
ten grondslag dat er een balans moet worden gevonden tussen (a) de proceseconomische gedachte achter het 'uitstellen' van de inhoudelijke behandeling en (b) een effectieve invulling van de 'inhoudelijke' elementen van de ontvankelijkheidstoets. Die twee uitgangspunten fungeren als toetsingskader.

$\mathrm{Bij}$ het beantwoorden van die vraag wordt inspiratie geput uit de ervaringen in de Verenigde Staten, waar een vergelijkbaar vraagstuk rechtspraak en literatuur lange tijd heeft beziggehouden. ${ }^{7}$ De federale class action verloopt daar namelijk al langere tijd volgens een tweetrapsstramien waarin ontvankelijkheidstoetsing aan inhoudelijke behandeling voorafgaat, en ook daar bevat de ontvankelijkheidstoets 'inhoudelijke' elementen, die een sterke verwantschap vertonen met de Nederlandse gelijksoortigheidseis. ${ }^{8}$ In de Verenigde Staten heeft dit tot veel discussie geleid over de vraag wat de rechter mag betrekken bij de beoordeling van de ontvankelijkheidseisen. De strikte scheiding tussen ontvankelijkheidstoets en inhoudelijke behandeling is in de Amerikaanse rechtspraak gaandeweg genuanceerd. ${ }^{9}$ De discussie daar makk inzichtelijk welke afwegingen daarbij kunnen spelen en heeft in dat licht relevantie voor de omgang met de preliminaire ontvankelijkheidstoets onder de WAMCA. ${ }^{10}$

De lijn van het betoog is als volgt. Allereerst wordt kort ingegaan op het nut van de procedurele tweesplitsing en de balans die daarbij moet worden gevonden (par. 2), waarna nader wordt ingegaan op de 'inhoudelijke' elementen van de ontvankelijkheidstoets (par. 3). Vervolgens komt het debat in de Verenigde Staten aan bod (par. 4). Het artikel sluit af met een aantal eerste gedachten over de omgang met de inhoudelijke' aspecten van de preliminaire ontvankelijkheidsbeslissing onder de WAMCA in het licht van de Amerikaanse discussie (par. 5) en een korte conclusie (par. 6).

\section{Controle aan de poort}

De regel van art. 1018c lid $5 \mathrm{Rv}$ wil dus, zoals Klaassen het uitdrukt, een 'harde knip' aanbrengen tussen de ontvankelijkheidstoets en de inhoudelijke behandeling van de vordering. ${ }^{11}$ Het doel daarvan is volgens de toelichting bij de WAMCA 'een lang en kostbaar debat over de inhoudelijke collectieve vordering te voorkomen in gevallen dat de collectieve vordering toch niet tot toewijzing kan leiden'. ${ }^{12}$ Vanuit een

7. R.A. Nagareda, 'Class certification in the age of aggregate proof, New York University Law Review (84) 2009, afl. 1, p. 99-100 en 111-114.

8. Zie par. 4.2 hierna.

9. L.S. Mullenix, 'Putting proponents to their proof: Evidentiary rules at class certification', The George Washington Law Review (82) 2014, afl. 3, p. 612-622.

10. Hoewel in dit artikel is gekozen voor een vergelijking met het Amerikaanse class action-recht, is het ook denkbaar een parallel te trekken met het Europese internationale bevoegdheidsrecht. Ook de toetsing van de rechtsmacht kan namelijk overlappen met de inhoudelijke beoordeling van de vordering van eiser, zie o.a. HvJ EU 28 januari 2015, C-375/13, ECLI:EU:C:2015:37 (Kolassa). De keuze voor een vergelijking met het Amerikaanse recht is ingegeven door de overweging dat de discussie in de VS in een (meer) vergelijkbare context speelt, i.e. preliminaire toetsing in een collectieve procedure. Bovendien is er in de VS veel over het vraagstuk geschreven.

11. Klaassen 2019, p. 150.

12. Kamerstukken II $2016 / 17,34608$, nr. 3, p. 39. oogpunt van proceseconomie valt er inderdaad veel te zeggen voor een preliminaire ontvankelijkheidsbeslissing als voorportaal van de collectieve procedure, waarin 'ongeschikte' zaken vroegtijdig worden weggefilterd.

Een collectieve actie is al gauw een project van lange adem, dat de nodige kosten voor partijen meebrengt en een verhoudingsgewijs groot beslag op schaarse rechtspraakcapaciteit legt. ${ }^{13}$ Die investering betaalt zich terug als de collectieve actie uiteindelijk leidt tot een schikking of einduitspraak met een voldoende grote mate van finaliteit. Strandt de collectieve rechtsvordering echter na (gedeeltelijke) inhoudelijke behandeling alsnog op een ontvankelijkheidsvereiste, op aanstonds evidente ondeugdelijkheid van de vordering of omdat de zaak (toch) ongeschikt bleek voor een collectieve actie, dan is er nodeloos tijd en moeite verspild. Vaak zal de oplossing van het geschil bovendien niet wezenlijk zijn bevorderd. Hoewel de minister vooral de positie van verweerders benadrukt, ${ }^{14}$ geldt voor alle betrokken partijen - belangenorganisaties, gedupeerden en de rechterlijke macht - dat dergelijke 'missers' beter kunnen worden vermeden.

Controle aan de poort in de vorm van een preliminaire ontvankelijkheidsbeslissing kan daarbij helpen. Vanuit een oogpunt van proceseconomie is het vervolgens verleidelijk om ook de discussie in de preliminaire fase 'klein' te houden, zodat 'ongeschikte' zaken snel en efficiënt worden weggefilterd en de afwikkeling van 'geschikte' zaken geen vertraging ondervindt. ${ }^{15}$ Het is echter een balanceeroefening. Het vooronderzoek moet voldoende diepgravend zijn om het kaf van het koren te scheiden, anders doet het meer kwaad dan goed. Een foutpositieve beslissing leidt tot onnodige en kansloze procedures, een foutnegatieve beslissing betekent dat de laagdrempelige toegang tot de rechter, die de collectieve rechtsgang aan benadeelden moet bieden, hun ten onrechte wordt ontzegd.

De vraag hoe met de 'inhoudelijke' elementen van de ontvankelijkheidstoets moet worden omgegaan, verdient in het kader van die balanceeroefening bijzondere aandacht. Deze elementen hebben de potentie om alsnog meer of minder uitvoerige inhoudelijke discussies in de voorfase binnen te laten, terwijl de procedurele tweesplitsing van art. 1018c lid $5 \mathrm{Rv}$ dat juist wenst te voorkomen. Anderzijds kan men die discussies ook weer niet geheel uit de weg gaan zonder de ontvankelijkheidstoets uit te hollen, zoals in de volgende paragrafen zal blijken.

13. Vgl. over de kosten voor een belangenorganisatie I.N. Tzankova, 'Wetsvoorstel collectieve schadevergoedingsactie: een oplossing voor welk probleem ook alweer?', TVP 2017, afl. 4, p. 112-113.

14. Kamerstukken II 2016/17, 34608, nr. 3, p. 40.

15. Vgl. Klaassen 2019, p. 150, die erop wijst dat de procedurele tweedeling van de WAMCA juist inefficiënt kan uitpakken als partijen in een uitvoerig debat over de ontvankelijkheidseisen verstrikt raken, maar de vordering in het volgende stadium al snel inhoudelijk ongegrond blijkt. 


\section{De 'inhoudelijke' elementen van de ontvankelijkheidstoets}

\subsection{Inleiding}

In deze paragraaf worden de hiervoor genoemde twee 'inhoudelijke' elementen van de ontvankelijkheidstoets, gelijksoortigheid en deugdelijkheid, nader besproken. Beide elementen hebben betrekking op het inhoudelijke geschil, maar moeten wel worden onderscheiden. Gelijksoortigheid (par. 3.2) ziet op een vraag die eigen is aan een collectieve actie, namelijk of het mogelijk is om een gemeenschappelijke beoordeling te verrichten ten aanzien van de gegrondheid van de in de collectieve actie gebundelde individuele vorderingen. Het onderzoek dat de rechter in het kader van de gelijksoortigheidstoets verricht, is bovendien medebepalend voor de afbakening van de 'nauw omschreven groep' personen in de zin van art. 1018e lid 2 Rv. ${ }^{16}$ Benadeelden kunnen immers slechts als één (sub)groep worden beschouwd voor zover hun individuele vorderingen zich voor een gezamenlijke beoordeling lenen. Summiere ondeugdelijkheid (par. 3.3) daarentegen ziet op de vraag of er een grond is voor het oordeel dat de vordering evident niettoewijsbaar is.

\subsection{Gelijksoortigheid}

De eis van gelijksoortige belangen is niet nieuw: hij stond al in het oude art. 3:305a BW, dat in 1994 werd ingevoerd. ${ }^{17}$ Volgens vaste rechtspraak is aan de eis voldaan, indien de belangen tot bescherming waarvan de collectieve rechtsvordering strekt zich voor bundeling lenen, zodat een efficiënte en effectieve rechtsbescherming ten behoeve van de belanghebbenden kan worden bevorderd. ${ }^{18}$ Hoewel de rechter er tot nog toe goed mee uit de voeten lijkt te kunnen, is de maatstaf enigszins ongelukkig geformuleerd. ${ }^{19}$ De nadruk die de wettelijke term en deze maatstaf op de te beschermen 'belangen' leggen, verhult wat in de meeste gevallen de prangende kwestie is bij toetsing aan het vereiste. Die is niet zozeer of de belangen van de bij de collectieve actie vertegenwoordigde personen 'gelijksoortig' of 'bundelbaar' zijn, maar of hun (gepretendeerde) individuele vorderingsrechten dat zijn. ${ }^{20} \mathrm{De}$ gelijksoortigheidseis veronderstelt namelijk dat de rechter beoordeelt of de feitelijke en rechtsvragen die bij de inhoudelijke beoordeling van de collectieve rechtsvordering moeten worden beantwoord in voldoende mate gemeenschappelijk

16. Vgl. Kamerstukken II 2016/17, 34608, nr. 3, p. 41.

17. Kamerstukken II 2016/17, 34608, nr. 3, p. 18. De eis was bovendien toen al een codificatie van bestaande rechtspraak, zie Kamerstukken II 1991/92, 26486, nr. 3, p. 3-7 en 27-28 en HR 27 juni 1986, ECLI:NL:HR:1986:AD3741, NJ 1987/743 (Nieuwe Meer), r.o. 3.2.

18. HR 26 februari 2010, ECLI:NL:HR:2010:BK5756, NJ 2011/473 (Baas in Eigen Huis/Plazacasa), r.o. 4.2.

19. Zie ook C.F. Kroes, 'Soortgelijke belangen, representativiteit en het bemoeizuchtbezwaar', NTBR 2010/43.

20. Die ongelukkige formulering leidt soms tot het - mijns inziens - misverstand dat voor gelijksoortigheid volstaat dat de vertegenwoordigde personen parallelle belangen hebben bij het gevorderde. Zie bijv. Rb. Amsterdam 24 juli 2019, ECLI:NL:RBAMS:2019:5392 (KNMT/ Buma), r.o. 4.7. Dat parallelle belang is zelden problematisch; de hamvraag is doorgaans of een collectieve beoordeling mogelijk is. zijn, zodat het mogelijk is om in één gezamenlijke procedure over de individuele vorderingsrechten van de benadeelden te oordelen, zonder dat daarbij de bijzondere omstandigheden aan de zijde van de individuele belanghebbenden betrokken hoeven te worden. ${ }^{21}$ Voldoende gemeenschappelijkheid in deze zin is bovendien een noodzakelijke voorwaarde voor vervulling van de eis dat de collectieve actie een efficiëntie- en effectiviteitsvoordeel biedt ten opzichte van individueel procederen of claimbundeling door middel van lastgeving of cessie. $^{22}$

Deze toetsingscriteria keren sinds de invoering van de WAMCA ook terug in art. 1018c lid 5 onder b Rv. Die bepaling is in wezen een explicitering van wat reeds uit de bestaande jurisprudentie volgt, met de toevoeging van een tweetal relevante gezichtspunten voor beoordeling van het relatieve efficiëntie- en effectiviteitsvoordeel van collectief procederen.

De gelijksoortigheidseis is te typeren als een logisch uitvloeisel van het bijzondere karakter van de procedure. Een collectieve rechtsvordering strekt ertoe dat de rechter in één procedure een gemeenschappelijk oordeel velt over een veelheid aan individuele vorderingsrechten, die in de collectieve vordering zijn verdisconteerd. De materieelprivaatrechtelijke normen aan de hand waarvan hij dat moet doen, zijn in de collectieve rechtsgang niet anders dan daarbuiten. ${ }^{23}$ Dat veroorzaakt wrijving, omdat die normen toegesneden zijn op individuele rechtsverhoudingen en, zeer strikt genomen, altijd een beoordeling van de omstandigheden van het individuele geval veronderstellen. Een collectieve actie beoogt dat niveau naar haar aard te overstijgen. Vanuit een oogpunt van rechtstoepassing is de combinatie van (a) collectief procederen ter (b) vaststelling van individuele rechten daarom een wat

21. Zie HR 26 februari 2010, ECLI:NL:HR:2010:BK5756, NJ 2011/473 (Baas in Eigen Huis/Plazacasa), r.o. 4.2; en zie voorts bijv. Rb. OostBrabant 29 juni 2016, ECLI:NL:RBOBR:2016:3383, r.o. 5.28-5.32; Hof 's-Hertogenbosch 22 januari 2019, ECLI:NL:GHSHE:2019:178, r.o. 6.3. Vgl. ook Pavillon 2019, p. 165; M.J. Kroeze, 'Collectieve acties en gelijksoortige belangen', Ondernemingsrecht 2004/190, p. 496-498.

22. Zie bijv. Rb. Gelderland 29 juli 2016, ECLI:NL:RBGEL:2016:4141, r.o. 3.5; Rb. Den Haag 18 oktober 2017, ECLI:NL:RBDHA: 2017:11807, r.o. 4.5; Rb. Amsterdam 25 april 2018, ECLI:NL:RBAMS:2018:2693, r.o. 4.4.

23. De wetgever wil daar met de WAMCA ook geen verandering in brengen. Zie Kamerstukken II 2016/17, 34608, nr. 3, p. 1. Door Hartlief is de vraag opgeworpen of de ontwikkeling van een bijzonder materieel 'massaschadevergoedingsrecht' (toch) noodzakelijk zal blijken. Zie T. Hartlief, 'Massaschade en de regelende rechter', NJB 2017/2138; T. Hartlief, 'Massaschaderecht in ontwikkeling', TPR 2019, p. 475. 
ongemakkelijke. ${ }^{24}$ Het is portretten schilderen met een verfroller.

De consequentie is dat niet elk massageschil geschikt is voor afwikkeling in een collectieve actie. Een praktische randvoorwaarde is immers dat de verzameling van individuele vorderingsrechten die de rechter krijgt voorgelegd, zich leent voor zo'n simultaanbeoordeling. Daarvoor moet voldoende kunnen worden geabstraheerd van de bijzonderheden van individuele gevallen. ${ }^{25}$ De gelijksoortigheidseis stelt daarom de vraag of een collectieve actie over de voorliggende zaak praktisch haalbaar is. Een (betrouwbaar) antwoord daarop geven - dat problemen in een later stadium voorkomt - vergt voldoende zicht op de contouren van de te verrichten inhoudelijke beoordeling. In die zin moet de rechter 'vooruitblikken'. ${ }^{26}$

De mogelijkheden voor een collectieve actie zijn afhankelijk van (a) de toe te passen materieelrechtelijke rechtsnormen en (b) de feiten (van de individuele gevallen) waarop ze ('veralgemeniseerd') toegepast moeten worden. ${ }^{27}$ Beide zijn 'afhankelijke variabelen', in die zin dat het partijdebat - afgezien van eventuele ambtshalve toetsingsplichten - in grote lijnen dicteert welke die normen zijn, en in het verlengende daarvan welke relevante feiten uit het totale feitenuniversum in de rechterlijke beoordeling moeten worden betrokken. Het is dus niet voldoende om kennis te nemen van de feitelijke en juridische grondslagen van de eis. Dat geeft namelijk alleen een volledig overzicht van de knelpunten die bij gemeenschappelijke inhoudelijke beoordeling van de vorderingsrechten van benadeelden kunnen rijzen, indien het beschouwd wordt in samenhang met de feitelijke en juridische grondslagen van de daartegen gerichte bestrijdende en bevrijdende verweren. Voor zover partijen elkaars stellingen betwisten, is bovendien van belang of zij ten minste een reële strategie hebben om het benodigde (tegen)bewijs op een 'collectief niveau' te leveren.

Het is daarom de vraag in hoeverre verweerders, ondanks de bevoegdheid die art. 1018c lid 5, laatste volzin, Rv hun ver-

24. Dat verklaart, meen ik, waarom de gelijksoortigheidseis zelden een obstakel vormt bij collectieve acties die voor een algemeen of meer ideëel belang opkomen (zoals Urgenda of de collectieve acties van Bureau Clara Wichmann). Daarbij doet de spanning tussen collectief procederen en individuele rechten zich niet of minder voor. Hoewel de theoretische constructie ook in dergelijke gevallen is dat de collectieve actie opkomt voor de gebundelde (grond)rechten van individuele burgers, staat er immers in wezen een zuiver collectief of algemeen belang ter discussie. Anders dan bij vermogensrechtelijk getinte collectieve acties is het in zulke gevallen immers niet goed denkbaar dat een benadeelde individueel over de materie procedeert. Vgl. N. Frenk, 'Bundeling van vorderingen', TPR 2003, p. 1417-1418. Zie over de problematiek van collectieve beoordeling van schadeclaims ook D.L. Barbiers, 'Beoordeling van schadevergoedingsvorderingen door de rechter in collectieve actie', NTBR 2020/35.

25. Vgl. HR 26 februari 2010, ECLI:NL:HR:2010:BK5756, NJ 2011/473 (Baas in Eigen Huis/Plazacasa), r.o. 4.2; G. Snijders, 'Collectief procederen: mogelijkheden en onmogelijkheden', in: E.J. Numann e.a. (red.), Massificatie in het privaatrecht. Opstellen ter gelegenheid van het 200jarig bestaan van het genootschap Iustitia et Amicitia, Deventer: Kluwer 2010, p. 132; N. Frenk, Kollektieve akties in het privaatrecht (diss. Utrecht), Deventer: Kluwer 1994, p. 98; Frenk 2003, p. 1449.

26. Pavillon 2019, p. 174.

27. Vgl. Snijders 2010, p. 132. schaft, hun inhoudelijke verweer in de praktijk daadwerkelijk zullen (kunnen) uitstellen tot na de preliminaire ontvankelijkheidsbeslissing. Wil een verweerder immers de ontvankelijkheid op het punt van de gemeenschappelijkheid gemotiveerd betwisten, dan zal hij zijn inhoudelijke verweer in ieder geval op hoofdlijnen moeten uitwerken en onderbouwen. Een betwisting van de gemeenschappelijkheid is immers in feite een betwisting van de voorstelling van zaken die de eiser aan zijn vordering ten grondslag legt. Betwist de verweerder de gemeenschappelijkheid niet, dan zal de rechter haar niettemin ambtshalve moeten beoordelen. ${ }^{28}$ Ook dan zal de rechter (doorgaans) moeten beschikken over het inhoudelijke verweer, wil hij een geïnformeerde beslissing kunnen nemen.

Voor een zinvolle toetsing van de gemeenschappelijkheid moeten de inhoudelijke geschilpunten tussen partijen voldoende zijn uitgekristalliseerd. Reeds om die reden bestaat er een zekere spanning met de in art. 1018c lid $5 \mathrm{Rv}$ besloten gedachte dat het inhoudelijke debat tot na de preliminaire ontvankelijkheidsbeslissing kan worden uitgesteld. Het is echter denkbaar om nog een stap verder te gaan. Zoals verderop bij de bespreking van het Amerikaanse recht zal blijken, kan de gemeenschappelijkheidstoets gebaat zijn bij een voorlopige beslissing van de rechter op bepaalde inhoudelijke geschilpunten die make or break zijn voor de vraag of de claims van benadeelden zich gezamenlijk laten afdoen (zie par. 4.4 onder b). Daarbij kan bijvoorbeeld worden gedacht aan de inroepbaarheid van een cruciaal causaliteitsvermoeden, zonder welk een individueel causaliteitsoordeel noodzakelijk is.

\subsection{Summiere ondeugdelijkheidstoets}

Inhoudelijke behandeling van de collectieve vordering vindt voorts slechts plaats, indien de rechter heeft beslist dat niet summierlijk van de ondeugdelijkheid van de vordering blijkt op het moment dat het geding aanhangig is gemaakt (art. 1018c lid $5 \mathrm{Rv}$ ). Het doel van deze regel is, in de woorden van de minister, om 'in uitzonderlijke gevallen een collectieve vordering al voor de inhoudelijke behandeling van tafel te krijgen omdat deze niet deugt. ${ }^{29}$

De toelichting is nogal kort van stof over de betekenis van die maatstaf: vermeld is slechts dat een gelijkluidend criterium bekend is van de regeling voor opheffing van een conservatoir beslag (art. $705 \mathrm{Rv}$ ) en dat de bepaling verwantschap toont met de motion to dismiss in het Amerikaanse recht. De term 'summierlijk blijken' keert overigens ook terug bij de faillietverklaring (art. 6 lid $3 \mathrm{Fw}$ ), waarvoor summierlijk moet blijken van feiten en omstandigheden die aantonen dat de schuldenaar in de toestand verkeert dat hij heeft opgehouden te betalen. ${ }^{30}$ In die context duidt de term op een kort, eenvoudig

28. De rechter dient immers zo nodig ambtshalve te toetsen of aan de drie voorvragen van art. $1018 \mathrm{c}$ lid $5 \mathrm{Rv}$ is voldaan, zie Kamerstukken II $2016 / 17,34608$, nr. 3, p. 39. Dit ligt ook voor de hand, omdat de ontvankelijkheidseisen voor collectieve acties mede strekken ter bescherming van de gedupeerden, die zelf geen partij in de procedure zijn.

29. Kamerstukken II 2016/17, 34608, nr. 3, p. 39.

30. En, indien een schuldeiser het faillissement aanvraagt, van diens vordering. 
onderzoek door de rechter. ${ }^{31}$ Aannemelijk is dat het begrip ook in de WAMCA tot uitdrukking brengt dat het om een beperkt onderzoek gaat.

Als voorbeeld van een geval waarin de bepaling toepassing kan vinden, noemt de toelichting een vordering die overduidelijk bij de bestuursrechter had moeten worden ingesteld. Dit voorbeeld betreft een formeel gebrek, dat weinig zegt over de inhoudelijke merites van de vordering, maar de verwijzingen naar de beslagrechtelijke regel en de motion to dismiss maken duidelijk dat ondeugdelijkheid (juist) ook op inhoudelijke gronden kan worden aangenomen. ${ }^{32}$

Ook De Bie Leuveling Tjeenk en Van de Velden gaan daarvan uit, maar menen dat de vergelijking met de Amerikaanse figuur voor het overige maar deels opgaat. ${ }^{33} \mathrm{Zij}$ wijzen er onder meer op dat de motion to dismiss naar Amerikaans recht een zeer beperkte toets impliceert, waarbij de rechter de feitelijke stellingen in de dagvaarding voor waar aanneemt en vervolgens beoordeelt of dat voldoende is om het beweerde vorderingsrecht prima facie aannemelijk te maken. De vraag daarbij lijkt dus, met andere woorden, of de aan de vordering ten grondslag gelegde feiten het gevorderde kunnen dragen - iets wat de Nederlandse rechter reeds ambtshalve na dient te gaan. ${ }^{34}$ Volgens De Bie Leuveling Tjeenk en Van de Velden zou de summiere ondeugdelijkheidstoets echter verder (moeten) gaan, omdat de rechter niet zonder meer van de juistheid van feitelijke stellingen in de dagvaarding hoeft uit te gaan, vooral niet als de verweerder aannemelijk maakt dat die stellingen kennelijk ongegrond zijn. Ik ben geneigd het daarmee eens te zijn, omdat het moeilijk met het doel van de bepaling te rijmen lijkt dat de rechter evident onjuiste stellingen voor waar zou moeten houden.

De toelichting maakt intussen niet duidelijk wat hier precies van de rechter wordt verwacht, zodat de rechtspraak enige ruimte heeft om nader vorm te geven aan de summiere ondeugdelijkheidstoets. Ook in dat verband is het interessant om kennis te nemen van de Amerikaanse literatuur, waarin veelvuldig is gepleit voor een ruime deugdelijkheidstoets in het voorportaal van de collectieve procedure. Ik kom daar verderop nog over te spreken (par. 4.4 onder c).

\section{Certification and the merits naar Amerikaans recht}

\subsection{Inleiding}

Ook in de Verenigde Staten is de vraag gerezen hoe scherp de scheidslijn tussen ontvankelijkheidsfase en inhoudelijke

31. N.J. Polak \& M. Pannevis, Insolventierecht, Deventer: Wolters Kluwer 2017, nr. 3.4 (online); J.B. Huizink, Insolventie, Deventer: Wolters Kluwer 2018, nr. 21 (online); Van den Sigtenhorst, in: T\&C Insolventierecht, art. $6 \mathrm{Fw}$, aant. 5 (online).

32. Zie over de inhoud van de toets in art. 705 lid $2 \mathrm{Rv}$ (o.m.) HR 25 november 2005, ECLI:NL:HR:2005:AT9060, NJ 2006/148 (Rohde Nielsen/De Donge).

33. J. de Bie Leuveling Tjeenk \& J.B. van de Velden, 'Collectief schadeverhaal vanuit de optiek van de aangesproken partij', Ondernemingsrecht 2017/85, p. 477-478.

34. Zie HR 13 november 2020, ECLI:NL:HR:2020:1785 (UTB Holding/ Glencore), r.o. 3.4.2. behandeling van een class action moet worden gezien. Die kwestie is bovendien lang contentieus geweest in rechtspraak en literatuur. In deze paragraaf komen de ontwikkelingen in de rechtspraak en de discussie in de literatuur aan bod (par. 4.3 en 4.4), nadat eerst het juridische kader kort is toegelicht (par. 4.2).

\subsection{Class action en class certification}

Class actions op de voet van Rule 23 van de Federal Rules of Civil Procedure (FRCP) zijn sinds jaar en dag onderworpen aan een formele preliminaire ontvankelijkheidsbeslissing, die in het jargon als class certification wordt aangeduid. ${ }^{35}$ De certification order vindt thans regeling in Rule 23(c) FRCP, volgens welke 'at an early practicable time after a person sues (...) as a class representative, the court must determine by order whether to certify the action as a class action'. De formulering van de bepaling verraadt een kenmerkend verschil met de Nederlandse collectieve actie. Anders dan in Nederland neemt in het Amerikaanse systeem niet een representatieve belangenorganisatie het voortouw, maar een individuele gedupeerde (lees: diens advocaten). Een class action vangt in eerste instantie aan als een individuele procedure van een gedupeerde die tot de beoogde class behoort, waarin vervolgens een motion for class certification wordt ingesteld. Daarmee verzoekt de eiser in wezen zijn individuele procedure tot een collectieve procedure op te schalen, met hem als de lead plaintiff of class representative. Geeft de rechter daarvoor groen licht, dan 'certificeert' hij de vordering als class action. Pas daarna vindt inhoudelijke behandeling van de (nu) collectieve vordering plaats, waarin de rechter (soms met een jury) de materieelrechtelijke gegrondheid van de aanspraken van de class members beoordeelt (trial).

Tenminste, als partijen niet aanstonds na certification schikken. In de praktijk monden verreweg de meeste class actions die de preliminaire toets passeren uit in een schikking tussen de class (representative) en de verwerende partij. ${ }^{36}$ Deze voorkeur voor schikken boven procederen kan worden verklaard door factoren als de hoge kosten die met een procedure zijn gemoeid, die elke partij volgens de zogenaamde 'American Rule' in principe zelf draagt, en onzekerheid over de omvang van de schadevergoeding die de rechter vaststelt. Een belangrijke consequentie van de hoge schikkingsgraad is intussen dat de preliminaire fase van de collectieve procedure vaak het

35. Zie R.G. Bone \& D.S. Evans, 'Class certification and the substantive merits', Duke Law Journal (51) 2002, p. 1259-1263. Terzijde: de oorspronkelijke tekst van de in 1966 ingevoerde Rule 23 FRCP hanteerde de term 'certification' overigens niet, hoewel het begrip destijds al wel in de rechtspraak werd gebruikt. Wijzigingen in 1998 en 2003 gaven de certification order een centrale plaats in de bepaling. Zie T.B. Wolff, 'Multiple attempts at class certification', Iowa Law Review (99) 2013, p. 139-141.

36. B.T. Fitzpatrick, 'An empirical study of class action settlements and their fee awards', Journal of Empirical Legal Studies (7) 2010, afl. 4, p. 812; S. Issacharoff \& R.A. Nagareda, 'Class settlements under attack', University of Pennsylvania Law Review (156) 2008, afl. 6, p. 1650. Hoewel schikken de norm blijft, constateert Klonoff recent wel een trend richting vaker procederen, R.H. Klonoff, 'Class actions in the year 2026: A prognosis', Emory Law Journal (65) 2016, afl. 6, p. 1641-1650. 
belangrijkste strijdtoneel is voor partijen - het is 'often the defining moment in class actions. ${ }^{37}$ Het is misschien met oog op dat gegeven dat de rechtspraak gaandeweg meer gewicht is gaan toekennen aan de toetsing bij certification. Het zwaartepunt van de procedure schuift ook daardoor meer richting het begin. Eén auteur omschrijft het treffend als een tendens tot 'front-loading class litigation'. ${ }^{38}$

In het kader van de certification toetst de rechter of de aangebrachte zaak voldoet aan de vereisten voor een class action. Hij bakent tevens de class en eventuele subclasses af en benoemt de class counsel. Rule 23(b) FRCP kent een aantal verschillende 'smaken' van collectieve acties, met enige onderlinge variatie in de toepasselijke toegangsvereisten en procedurele modaliteiten. ${ }^{39}$ In de praktijk is de variant van Rule 23(b)(3) FRCP verreweg de belangrijkste, omdat deze in de meeste gevallen de enige grondslag is waarop in collectief verband schadevergoeding kan worden gevorderd. ${ }^{40}$ Men spreekt om die reden ook wel van de damages class action.

Verzoekt de eiser op die grondslag class certification, dan moet er, kort gezegd, een zestal zaken komen vast te staan. Allereerst moet (1) in verband met de omvang van de beoogde class het alternatief van een gevoegde behandeling van individuele zaken onpraktisch zijn (numerosity). Verder moeten (2) er binnen de class gemeenschappelijke feitelijke vragen of rechtsvragen spelen (commonality), en moet (3) de vordering van de vertegenwoordigende eiser representatief of 'typisch' zijn voor de vorderingen van de class (typicality). Omdat de procedure uiteindelijk mede - of eigenlijk: hoofdzakelijk - moet leiden tot vaststelling van de rechten van de niet zelf ten processe aanwezige class members, is bovendien van belang (4) of de class representative geacht kan worden hun belangen op een billijke en adequate wijze te behartigen (adequacy of representation). Dit zijn de algemene vereisten. Voor een damages class action moet voorts komen vast te staan dat (5) de gemeenschappelijke feitelijke kwesties en rechtsvragen de overhand hebben op individuele vragen (predominance), en (6) dat voor een billijke en efficiënte beslechting van het geschil een class action is te prefereren boven de beschikbare alternatieven (superiority).

Het moge duidelijk zijn dat de commonality- en predominance-vragen naar hun aard nauw met de inhoudelijke

37. Aldus de Court of Appeals for the Third Circuit in Newton v. Merrill Lynch, Pierce, Fenner \& Smith, Inc., 259 F.3d 154 (3rd Cir. 2001), op p. 162.

38. R.D. Freer, 'Front-loading, avoidance, and other features of the recent Supreme Court class action jurisprudence', Akron Law Review (48) 2015, afl. 4, p. 723. Zie ook Mullenix 2014, p. 612-622.

39. Zie Rule 23(b) FRCP. De vier 'kernvereisten' opgesomd in Rule 23(a) FRCP gelden voor alle verschijningsvormen van de class action.

40. De mogelijkheden om schadevergoeding te vorderen op de alternatieve grondslagen zijn tot een aantal specifieke situaties beperkt, omdat alleen onder Rule 23(b)(3) FRCP de belangrijke waarborg van een opt-outmogelijkheid aan de benadeelden wordt geboden. behandeling van de collectieve vordering zijn verbonden. ${ }^{41} \mathrm{De}$ criteria zijn in theorie van elkaar te onderscheiden, maar plegen bij de rechterlijke beoordeling in de certification-fase door elkaar heen te lopen. Het onderliggende vraagstuk is in beide gevallen immers de haalbaarheid van een collectieve beoordeling. In samenhang met het superiority-vereiste volgt uit deze criteria dus een toets van (min of meer) gelijke strekking en functie als de Nederlandse gelijksoortigheidseis.

Ook bij de class action van Rule 23 FRCP doet zich derhalve de ongemakkelijke situatie voor dat er enerzijds een formele procedurele tweedeling is tussen ontvankelijkheidstoetsing en inhoudelijke behandeling, terwijl anderzijds de in die preliminaire fase te verrichten ontvankelijkheidstoets bepaalde 'inhoudelijke' elementen bevat die de rechter uitnodigen, zo niet noodzaken, om over de schutting heen te kijken.

\subsection{De Eisen-zaak}

De vraag in hoeverre de rechter om die reden bij certification vooruit mag (of moet) lopen op de inhoudelijke behandeling en beoordeling van de class action, is lang controversieel geweest in de Amerikaanse rechtspraak en literatuur. ${ }^{42}$ Die controverse vindt haar oorsprong in een uitspraak die de Supreme Court medio jaren zeventig deed, bekend als Eisen $v$. Carlisle \& Jacquelin, of kortweg Eisen. ${ }^{43}$ Het betrof een class action ten behoeve van kleine effectenhandelaren die waren benadeeld doordat effectenmakelaar Carlisle \& Jacquelin zijn toenmalige monopolistenpositie had misbruikt om excessief hoge commissies te hanteren. De kosten van de door Rule 23(c)(2) FRCP vereiste individuele kennisgeving aan class members, die in ieder geval in eerste instantie ten laste van de eisende partij zouden komen, bleken echter een groot obstakel.

Om te voorkomen dat de class action een vroege dood zou sterven en geen van de benadeelde handelaars een kans op verhaal zou hebben, 'frustrating (...) the policy behind private antitrust actions', ${ }^{44}$ besloot de District Court te onderzoeken of de verweerder met de kosten van kennisgeving kon worden belast. Dat moest echter geen arbitraire en oneerlijke last op de verweerder leggen op grond van een immers mogelijk ongegronde vordering. De District Court verrichtte daarom in het

41. Vgl. G.P. Miller, 'Review of the merits in class action certification', Hofstra Law Review (33) 2004, afl. 1, p. 52-54. Ook het vereiste van typicality is overigens verweven met de inhoudelijke grondslagen van de vordering. Typicality ziet echter niet zozeer op de haalbaarheid van een collectieve actie, als wel op (een aspect van) de vraag of de named/lead plaintiff een geschikte vertegenwoordiger van de class is. Het ligt daarmee dicht tegen het vereiste van adequacy of representation aan. Het Nederlandse recht kent geen tegenhanger van de typicality-eis, omdat hier te lande een representatieve belangenorganisatie als vertegenwoordiger optreedt in plaats van een lid van de groep benadeelden. Ik laat de typicality verder buiten beschouwing.

42. R.A. Nagareda, 'Common answers for class certification', Vanderbilt Law Review En Banc (63) 2010, p. 149-151; Nagareda 2009, p. 99-100.

43. Eisen v. Carlisle \& Jacquelin, 417 U.S. 154 (1974). Zie over de achtergrond en processuele voorgeschiedenis o.m. R. Marcus, 'Revising judicial gatekeeping of aggregation: Scrutinizing the merits on class certification', The George Washington Law Review (79) 2011, afl. 2, p. 332-341.

44. Eisen, 417 U.S. 154 (1974), op p. 168. 
kader van de certification een onderzoek naar de kans dat de vordering bij inhoudelijke behandeling gegrond zou worden bevonden. Ze concludeerde daaruit dat toewijzing 'more than likely' was en droeg de verweerder op om $90 \%$ van de kosten voor kennisgeving te voldoen.

Die pragmatische benadering vond geen genade bij de Supreme Court, die oordeelde dat de District Court de kosten van die kennisgeving niet op de verweerder had mogen leggen. Dat oordeel keerde zich niet zozeer tegen de kostenverschuiving als zodanig, als wel tegen de wijze waarop de lagere rechter daartoe was gekomen: door op de inhoudelijke behandeling vooruit te lopen. Volgens de Supreme Court heeft de rechter in het kader van de certification namelijk geen '(...) authority to conduct a preliminary inquiry into the merits of a suit in order to determine whether it may be maintained as a class action. ${ }^{45}$ Dat zou, vrij parafraserend, namelijk indruisen tegen de procedurele tweedeling waar Rule 23 van uitgaat, doordat het eiser het voordeel verschaft van een rechterlijk oordeel over de claims van de class, nog voordat is vastgesteld dat aan de voorwaarden voor een class action is voldaan. De Supreme Court uitte bovendien de zorg dat een 'preliminary determination of the merits' verweerders zou kunnen benadelen. Een voorlopig oordeel over de merites van de vordering zou de latere inhoudelijke behandeling kleuren, maar niet met de gebruikelijke procedurele waarborgen zijn omgeven.

De hierboven aangehaalde frase waarin de Supreme Court een 'preliminary inquiry into the merits' verbiedt, is later bekend geworden als de 'Eisen rule' en is inmiddels een pijler van de class action-praktijk. ${ }^{46}$ Toch heeft er lang onduidelijkheid bestaan over de reikwijdte en gestrengheid van het verbod. ${ }^{47}$ Lagere rechters hebben in de jaren na Eisen (soms sterk) uiteenlopende toetsingsmaatstaven gehanteerd voor de inhoudelijke elementen van de certification-beslissing. ${ }^{48}$ Ook in de literatuur zijn verschillende opvattingen verdedigd, waarbij sommige auteurs in twijfel trekken of het verbod überhaupt wenselijk is.

\subsection{Rechtspraak en literatuur}

Volgens de Amerikaanse rechtsgeleerde Miller zijn de verschillende benaderingen voor de preliminaire beoordeling grofweg in drie categorieën te verdelen, naar de mate waarin het de rechter is toegestaan om bij certification een voorschot te nemen op de inhoudelijke behandeling van de zaak. Ik zal zijn typologie in deze paragraaf als kapstok gebruiken, hoewel ik mij niet beperk tot de argumenten die hij bespreekt.

Miller onderscheidt 'strong-form rules', 'weak-form rules' en 'super-weak rules'. ${ }^{49}$ Regels van de eerste categorie verbieden een inhoudelijk onderzoek naar de vordering ('inquiries into the merits'). Regels van de tweede categorie staan een

45. Eisen, 417 U.S. 154 (1974), op p. 177.

46. Miller 2004, p. 51.

47. Marcus 2011, p. 341.

48. J. Slater, 'Reaping the benefits of class certification: How and when should significant proof be required post-Dukes?', BYU Law Review 2011, afl. 4, p. 1264-1265.

49. Miller 2004, p. 51-52 inhoudelijk onderzoek toe, maar binnen redelijke grenzen en uitsluitend voor zover relevant voor een beslissing ten aanzien van de ontvankelijkheidsvoorwaarden van Rule 23 FRCP. ${ }^{50}$ Regels van de derde categorie, ten slotte, stellen geen restricties aan inhoudelijk onderzoek in de preliminaire fase. Integendeel: ze staan toe of verlangen zelfs dat de rechter een inschatting maakt van de kans dat de vordering uiteindelijk gegrond zal worden bevonden, voordat hij een class action sanctioneert. Deze drie benaderingen duid ik hierna ook wel aan als respectievelijk (a) de strenge leer, (b) de gematigde leer en (c) de vrije leer.

\section{Ad a. De strenge leer (strong-form rules)}

Onder een strong-form rule verricht de rechter voor de certification-beslissing geen of hooguit een oppervlakkig onderzoek naar het inhoudelijke geschil. Hij beperkt zich tot een 'geïsoleerde' toetsing van de ontvankelijkheidsvoorwaarden van Rule 23 FRCP. Waar die eisen sterk met de inhoudelijke beoordeling van de vordering zijn verweven, dwingt de strenge leer de rechter tot grote terughoudendheid: de rechter 'may not go beyond the face of the pleadings with respect to any issues relating to the merits, but must instead accept as true the well-pleaded allegations in the complaint'. ${ }^{51}$

Naar ik begrijp, pleegt men dat niet zó strikt op te vatten, dat het de rechter niet vrijstaat om een eigen analyse te maken van de juridische en feitelijke elementen die in enerzijds de stellingen van eiser en anderzijds het verweer van de aangesproken partij besloten liggen, om zich zo een beeld te vormen van wat er bij een inhoudelijke behandeling van de collectieve vordering zou kunnen komen kijken. ${ }^{52}$ De eiser kan dus niet volstaan met enkel stellen dat aan de gemeenschappelijkheidsvereisten is voldaan. Dat zal hij moeten onderbouwen. Voor die onderbouwing volstaat echter een verwijzing naar de juridische en feitelijke stellingen die hij aan zijn (inhoudelijke) vordering ten grondslag legt, dit onder vermelding van de voor gemeenschappelijke beantwoording vatbare vragen die daar volgens hem uit blijken. De rechter zal er bij de certificationbeslissing veronderstellenderwijs van uitgaan dat die stellingen, zo ze voldoende zijn gemotiveerd, kloppen. Hij zal dus niet de inhoudelijke merites van de stellingen beoordelen of enig bewijs en tegenbewijs waarderen. Dat is niet anders indien de verweerder de juistheid van eisers stellingen betwist op een wijze die, indien ze doel treft, ertoe leidt dat de voor de haalbaarheid van een collectieve beoordeling vereiste cohesie van (de claims van) de class wordt doorbroken.

Het effect van een strong-form rule laat zich illustreren aan de hand van een vereenvoudigd voorbeeld. Eiser A komt op voor een groep consumenten die product $\mathrm{X}$ hebben gekocht van producent $\mathrm{B}$. A stelt dat alle exemplaren van product $\mathrm{X}$

50. Voor de goede orde: ik spits mijn voorbeelden hieronder toe op de commonality- en predominance-eisen, omdat hun toepassing het vaakst aanleiding geeft tot vragen over de verhouding tussen ontvankelijkheidstoets en inhoudelijke fase. Wat voor die eisen geldt, geldt eveneens voor de overige ontvankelijkheidsvoorwaarden van Rule 23 FRCP.

51. Miller 2004, p. 55-59. Citaat ontleend aan p. 55, waar Miller de frase als de meest gangbare formulering van een strong-form rule omschrijft.

52. Vgl. Bone \& Evans 2002, p. 1266 en 1277; Miller 2004, p. 55. 
een defect vertonen, waardoor het product niet de eigenschap $Y$ heeft waarmee B heeft geadverteerd. A eist een prijsreductie ten behoeve van de kopers. B verweert zich en voert aan: (1) dat niet elk exemplaar van $\mathrm{X}$ een defect vertoont, omdat product $\mathrm{X}$ op meerdere locaties volgens verschillende productieprocessen wordt gefabriceerd en slechts één van die productieprocessen mogelijk tot het bestreden defect zou kunnen leiden; (2) dat het bestreden defect ook ontstaat bij een onzorgvuldig gebruik van $\mathrm{X}$ door de koper; en (3) dat $\mathrm{B}$ geen uniforme mededelingen aan de kopers heeft gedaan over de eigenschappen van $\mathrm{X}$, waardoor de vraag of een koper eigenschap Y mocht verwachten van geval tot geval verschilt. Als deze stellingen van B hout snijden, dan is het maar de vraag of de claims van de class zich voor een gemeenschappelijke beoordeling lenen. De rechter die een strong-form rule hanteert, zal geen voorlopig oordeel geven over de vraag welke van deze botsende lezingen juist is, en zal er vooralsnog van uitgaan dat de stellingen van A waar (kunnen) zijn. Bijgevolg zal hij de class action vermoedelijk certificeren, hoewel er nog redelijke twijfel bestaat of de claims daadwerkelijk voldoende gelijksoortig zijn om een class action zinvol te maken.

De strenge leer betekent per saldo dat de rechter zijn oordeel omtrent de haalbaarheid van een collectieve beoordeling - commonality, predominance en daarop voortbouwend superiority - baseert op het plaatje dat (een der) partijen voor hem schilderen (schildert). Ten faveure van die minimalistische benadering is wel aangevoerd dat ze uitdijing van de preliminaire fase in termen van tijd en kosten voorkomt. ${ }^{53}$ Het is echter de vraag of het genoeg is om een zinvolle invulling te geven aan de haalbaarheidstoets, al was het maar omdat die partijen er een evident belang bij hebben om een geïdealiseerde respectievelijk gedramatiseerde voorstelling van zaken te geven. ${ }^{54}$ Het realiteitsgehalte van die voorstellingen blijft een open vraag totdat men aan de inhoudelijke behandeling toekomt. Strong-form rules brengen zodoende een risico mee dat de discussie over de vraag of en hoe de voorliggende zaak collectief kan worden afgedaan, wordt gevoerd op een (te) abstract en theoretisch niveau. ${ }^{55}$ Dat vergroot de kans dat de rechter in de preliminaire fase een verkeerde inschatting van de zaak maakt.

Mede om deze reden - een hoog risico op certification error - lijkt de rechtsgeleerde literatuur de strenge leer overwe-

53. Miller 2004, p. 82; Bone \& Evans 2002, p. 1277; A.R. Miller, 'Of Frankenstein monsters and shining knights: Myth, reality, and the "class action problem”', Harvard Law Review (92) 1979, afl. 3, p. 689; S.D. Olson, "Chipping away": The misguided trend toward resolving merits disputes as part of the class certification calculus', University of San Francisco Law Review (43) 2009, afl. 4, p. 952-966; Marcus 2011, p. 355 .

54. Vgl. Bone \& Evans 2002, p. 1268-1270.

55. Op dit laatste wijzen bijv. Bone \& Evans 2002, p. 1270. gend af te keuren. ${ }^{56}$ En hoewel in de rechtspraak met name in de vroege jaren na Eisen regelmatig strong-form rules zijn gehanteerd, ${ }^{57}$ heeft die benadering door voortschrijdend inzicht ook daar gaandeweg veel terrein verloren. Zo constateert Nagareda dat er na de eeuwwisseling onder de federal appellate courts een consensus is ontstaan die de strenge leer van de hand wijst ten gunste van de hierna te bespreken gematigde leer. ${ }^{58}$

In zekere zin is het vreemd dat dit pas zo laat is gebeurd. De Supreme Court benadrukte in Falcon - luttele jaren na Eisen - dat de rechter alleen een class action mag certificeren na een 'rigorous analysis' van de voorwaarden van Rule 23 FRCP. Hij liet daarbij doorschemeren dat de rechter niet zomaar op de stellingen van eiser kan afgaan, ${ }^{59}$ en gaf eerder al aan dat de certification-beoordeling is verweven met de feitelijke en juridische grondslagen van de actie. ${ }^{60}$ Dat verdraagt zich minder goed met de toets die een strong-form rule impliceert. De omstandigheid dat de Supreme Court dat niet als een breuk met Eisen beschouwde, was een indicatie dat in Eisen niet een omarming van de strenge leer moest worden gelezen. ${ }^{61}$ De meest duidelijke veroordeling van de strenge leer sprak de Supreme Court pas in 2011 uit in Wal-Mart Stores, Inc. v. Dukes:

'Rule 23 does not set forth a mere pleading standard. (...) [Certification] is proper only if the trial court is satisfied, after a rigorous analysis, that the pre-requisites of [Rule 23] have been satisfied (...) Frequently that "rigorous ana-

56. Zie voor het certification error-argument o.m. Miller 2004, p. 65-66 en 84-85; Bone \& Evans 2002, p. 1276 e.v.; Evans 2002, p. 2-3 en 9-10; D.M. Towns, 'Merit-based class certification: Old wine in a new bottle', Virginia Law Review (78) 1992, afl. 4, p. 1032-1033; G. Rutherglen, 'Title VII class actions', University of Chicago Law Review (47) 1980, p. 727-728; Marcus 2011, p. 355; S.H. Yeager, 'In re New Motor Vehicles Canadian Export Antitrust Litigation: Examining the requisite levels of inquiry into the merits of a case at the class certification stage', Delaware Journal of Corporate Law (34) 2009, p. 575-580. Kritisch over het gebruik van weak-form (of super-weak) rules zijn bijv. Olson 2009, p. 935-978; J.P. Davis \& E.L. Cramer, 'Of vulnerable monopolists: Questionable innovation in the standard for class certification in antitrust cases', Rutgers Law Journal (41) 2009, p. 355-402; J.A. Osefchen $\&$ P.S. Fuoco, 'New Jersey parts company with the federal courts on whether to consider merits issues on class certification', Rutgers Law Journal (59) 2011, p. 59-76. Deze critici vrezen vooral dat vertrek van strong-form rules de drempel voor collectieve acties verhoogt.

57. Zie Bone \& Evans 2002, p. 1266 met talrijke verwijzingen; Mullenix 2014, p. 614-616

58. Nagareda 2010, p. 149-151. Zie ook Nagareda 2009, p. 99-100.

59. General Telephone Co. of Southwest v. Falcon, 457 U.S. 146 (1982), op p. 160-161.

60. Coopers \& Lybrand v. Livesay, 437 U.S. 463 (1978), op p. 469.

61. Verschillende commentatoren hadden er voor Dukes al op gewezen dat de Supreme Court met Eisen niet een strong-form rule omarmde, maar vermoedelijk slechts afstand beoogde te nemen van een super-weak rule. Bijv. Rutherglen 1980, p. 733; D.S. Evans, 'Class certification, the merits, and expert evidence', George Mason Law Review (11) 2002, afl. 1, p. 9-10; Miller 2004, p. 63-64. 
lysis" will entail some overlap with the merits of the plaintiff s underlying claim. That cannot be helped. ${ }^{62}$

In diezelfde uitspraak merkt de Supreme Court op dat zijn overwegingen in Eisen soms ten onrechte worden opgevat als een algeheel verbod op een inhoudelijk onderzoek in de preliminaire fase. Waar het oordeel zich in Eisen tegen keerde, was een inhoudelijk onderzoek dat geen verband hield met de vereisten van Rule 23 FRCP. ${ }^{63}$

\section{Ad b. De gematigde leer (weak-form rules)}

$\mathrm{Na}$ Dukes lijkt er weinig twijfel mogelijk dat de gematigde leer naar geldend recht de juiste taakopvatting is van de rechter die op een motion for class certification beslist. ${ }^{64}$ Ook onder een weak-form rule is de preliminaire fase louter gericht op een toetsing van de vereisten van Rule 23 FRCP. Anders dan bij een strong-form rule is de rechter daarbij echter bevoegd (volgens sommigen: verplicht ${ }^{65}$ ) om binnen redelijke grenzen een inhoudelijk onderzoek naar de vordering in te stellen, voor zover dat relevant is voor zijn beslissing ten aanzien van die ontvankelijkheidseisen. ${ }^{66}$

Concreet betekent dit dat de rechter de stellingen van eiser noch verweerder zonder meer voor waar aanneemt, maar dat hij zo nodig reeds in de preliminaire fase een wederzijdse bewijsvoering verlangt en bewijs waardeert. Hij volstaat niet met het identificeren van vragen die volgens de lezing van eiser dan wel verweerder mogelijk (on)gemeenschappelijk zijn, maar beoordeelt of die vragen zich inderdaad voor gemeenschappelijke beantwoording zullen lenen. ${ }^{67}$ Dat vereist een grondige en in het bewijs gefundeerde analyse van zowel hetgeen eiser aan de vorderingen als hetgeen verweerder aan zijn verweren ten grondslag legt. In voorkomende gevallen geeft de rechter een voorlopig oordeel - waaraan hij in de inhoudelijke fase niet is gebonden - over de inhoudelijke feitelijke of juridische geschilpunten die cruciaal zijn voor de vraag of een gemeenschappelijke beoordeling van de claims van class members mogelijk zal zijn. ${ }^{68}$ In het hiervoor genoemde voorbeeld van eiser A en producent B zou de rechter kunnen onderzoeken of de 'gemeenschappelijkheidsondermijnende' stellingen van B inderdaad hout snijden, alvorens de class action over product $\mathrm{X}$ te certificeren.

62. Wal-Mart Stores, Inc. v. Dukes, 564 U.S. 338 (2011), op p. 350-351 (intern citaat weggelaten). Deze lijn werd bevestigd in Amgen, Inc. v. Connecticut Retirement Plans and Trust Fund, 133 S.Ct. 1184 (2013) en Comcast Corp. v. Behrend, 569 U.S. 27 (2013).

63. Dukes, 564 U.S. 338 (2011), op p. 350-351 (voetnoot 6-7).

64. Zie nadien expliciet Amgen, 133 S.Ct. 1184 (2013), op p. 1194-1195. Vgl. voorts Slater 2011, p. 1264-1265, Mullenix 2014, p. 615-616 en het overzicht van lagere rechtspraak na Dukes in G.H. Smoger \& D.M. Arbogast, "The post-Dukes "rigorous analysis" and pre-certification', The George Washington Law Review (82) 2014, p. 107-127.

65. Zie bijv. American Law Institute (ALI), Principles of the law of aggregate litigation, St. Paul: ALI Publishers 2010, p. 139 (\$2.06); In re Hydrogen Peroxide Antitrust Litig., 552 F.3d 305 (3rd Cir. 2008), op p. 307 e.v.

66. Miller 2004, p. 59-62.

67. Vgl. Nagareda 2010, p. 152.

68. Deze opvatting wordt bijv. helder verwoord in ALI 2010, p. 139 en 147 $(\$ 2.06)$.
De praktische betekenis van deze benadering komt duidelijk naar voren in class actions over beweerde misleiding op effectenmarkten (securities fraud). Hetzelfde voorbeeld haalde de Supreme Court in Dukes aan ter illustratie van het soort inhoudelijk onderzoek dat de rechter voor de certification-beslissing soms moet verrichten. ${ }^{69}$ Beleggers die op basis van misleidende informatie hebben gehandeld en daardoor zijn benadeeld, kunnen onder omstandigheden hun schade op de verantwoordelijke partij verhalen. Voor het slagen van zo'n misrepresentation claim is materieelrechtelijk in beginsel een causaal verband tussen het handelen van de individuele belegger en de misleidende mededelingen (individual reliance) noodzakelijk. Dat wordt doorgaans beschouwd als een (onoverkoombaar) obstakel voor gemeenschappelijke beoordeling van zulke claims in een class action, omdat het geïndividualiseerd bewijs en een geïndividualiseerde beoordeling vergt. Dit probleem 'verdampt' echter als de class representative erin slaagt het causaliteitsvermoeden onder de zogenaamde 'fraudon-the-market doctrine' te activeren. ${ }^{70}$

In securities fraud class actions is de vraag of dit causaliteitsvermoeden kan worden ingeroepen vaak zo'n inhoudelijk geschilpunt dat het cruciaal is voor de vraag of afwikkeling van de claims in een collectieve procedure haalbaar is. Rechters die de gematigde leer toepassen, stellen een beoordeling van de inroepbaarheid van dit vermoeden niet uit tot de inhoudelijke fase. Ze geven een voorlopige beslissing over het geschilpunt, ten behoeve waarvan ze reeds in dit vroege stadium het relevante bewijs en tegenbewijs waarderen. ${ }^{71}$ Het is onder die omstandigheden immers een 'threshold issue' voor de beantwoording van de predominance-vraag van Rule 23(b)(3) FRCP. ${ }^{72}$

Het belangrijkste voordeel van deze benadering is vanzelfsprekend dat ze de rechter beter in staat stelt om de haalbaarheid van een collectieve beoordeling in te schatten. Dat verkleint de kans dat procedures in een later stadium stuklopen en kan selectie op zaken met een goed 'finaliteitsperspectief faciliteren. Daar staat een verzwaring van de preliminaire fase tegenover, maar die trade-off kan de moeite waard zijn als daardoor minder 'ongeschikte' zaken het voorportaal passeren.

Het voorbeeld laat tevens zien hoe de haalbaarheidsvraag ('Leent deze zaak zich voor beoordeling als een collectieve actie?') en de deugdelijkheidsvraag ('Is deze vordering toewijsbaar?') kunnen overlappen. De voorlopige beslissing over het

69. Dukes, 564 U.S. 338 (2011), op p. 351 (voetnoot 6).

70. Deze regel is gegrond op inzichten uit de economie. De gedachte is, kort gezegd, dat in een efficiënte markt met een perfecte informatiebeschikbaarheid een ongecorrigeerde misleidende mededeling altijd in de handelsprijs van de betrokken effecten is verdisconteerd, waardoor elke handelaar die in het relevante tijdvak heeft gehandeld, geacht kan worden zijn handelen op de misleidende informatie te hebben gebaseerd. Om het vermoeden te activeren zal de eiser o.m. moeten aantonen dat de relevante markt in voldoende mate de kenmerken van een efficiënte markt vertoont. De verweerder kan het causaliteitsvermoeden overigens in individuele gevallen weerleggen. Zie Basic, Inc. v. Levinson, 485 U.S. 224 (1988).

71. Bijv. In re Initial Public Offering Securities Litigation, 471 F.3d 24 (2nd Cir. 2006), op p. 42-43. Vgl. ook Bone \& Evans 2002, p. 1278.

72. Zie Nagareda 2010, p. 163-165. 
causaliteitsvermoeden is van belang voor de vraag of de claims van gedupeerden zich voor gemeenschappelijke beoordeling lenen, maar betreft tevens een oordeel over een essentieel element voor gegrondheid van de collectieve vordering. Met een bevestigend antwoord is nog niet gezegd dat de vordering in alle waarschijnlijkheid zal worden toegewezen. De rechter betrekt immers niet alle doch slechts de voor de haalbaarheid kritieke geschilpunten in zijn ontvankelijkheidsoordeel. Dat oordeel is bovendien voorlopig van aard en staat (in ieder geval in theorie) in de inhoudelijke fase opnieuw ter discussie.

\section{Ad c. De vrije leer (super-weak rules)}

Ook onder een super-weak rule, ten slotte, beoordeelt de rechter in de preliminaire fase of aan de eisen van Rule 23 FRCP is voldaan en mag hij in dat kader een inhoudelijk onderzoek verrichten, waarbij hij zo nodig een voorlopige inhoudelijke beslissing geeft als dat dienstig is voor de beslissing ten aanzien van de ontvankelijkheidseisen. In zoverre verschilt deze benadering niet van een weak-form rule.

Bij een super-weak rule beoordeelt de rechter daarentegen ook de kans dat de vordering na inhoudelijke behandeling uiteindelijk gegrond wordt bevonden. ${ }^{73}$ Schat hij die kans te laag in, dan zal hij in het uiterste geval certification weigeren, ook als overigens wel aan de eisen van Rule 23 FRCP is voldaan. Er wordt dus naast de haalbaarheidstoets (toetsing van de eisen van commonality, predominance, enzovoort) ook een deugdelijkheidstoets geïntroduceerd. Opvattingen over de bij die deugdelijkheidstoets aan te leggen maatstaf verschillen. ${ }^{74} \mathrm{Wel}$ lijken voorstanders de rechter doorgaans een ruime discretionaire bevoegdheid toe te kennen om per geval de omvang en diepgang van dat preliminaire onderzoek naar de gronden te bepalen. ${ }^{75}$ Dit onderzoek en een eventuele pre-certificationbewijsvoering hoeven zich - anders dan bij een weak-form rule - niet te beperken tot datgene wat voor de beoordeling van de ontvankelijkheidsvoorwaarden van Rule 23 FRCP relevant is, maar kunnen het gehele inhoudelijke geschil betreffen.

Toepassingen van deze benadering in de praktijk zijn zeldzaam en komt men zeker in recente rechtspraak niet meer tegen. ${ }^{76} \mathrm{Ze}$ is immers duidelijk niet met de Eisen-regel te

73. Miller 2004, p. 62.

74. Zo bepleiten Bone en Evans (2002, p. 1278) een 'likelihood of success'toets, waarbij de rechter 'must give merits issues some attention and evaluate whether they are viable under a standard that would give the plaintiff some benefit of the doubt, but not a free pass'. In Dolgow $v$. Anderson, 43 F.R.D. 472 (E.D.N.Y. 1968), op p. 501, werd een 'substantial possibility that [plaintiffs] will prevail on the merits' verlangd, een maatstaf die ook door McGuire, 168 F.R.d. 366 (1996), op p. 396-400, wordt omarmd. Ook een maatstaf waarbij 'sufficiently serious questions going to the merits to make them fair grounds for litigation' zijn vereist, is voorgesteld. Zie Rutherglen 1980, p. 729 met verdere verwijzingen. Veel auteurs die super-weak rules bepleiten, laten overigens in het midden hoe het criterium zou moeten luiden.

75. Zie bijv. McGuire, 168 F.R.d. 366 (1996), op p. 401-402; Towns 1992, p. 1040; Bone \& Evans 2002, p. 1330.

76. Voorbeelden zijn Dolgow, 43 F.R.D. 472 (E.D.N.Y. 1968); In re RhonePoulenc Rorer, Inc, 51 F.3d 1293 (7th Cir. 1995). verenigen. ${ }^{77}$ In de rechtsgeleerde literatuur is ze echter door verschillende auteurs verdedigd. ${ }^{78}$ Mogelijk hangt de populariteit die de vrije leer onder commentatoren geniet samen met het besef dat de inhoudelijke behandeling van de collectieve vordering - waarvoor de rechter zijn inhoudelijke onderzoek moet 'bewaren' - in de praktijk vaak eenvoudigweg niet plaatsvindt, omdat partijen na certification schikken. Hun argumenten voor super-weak rules focussen namelijk vaak op het effect dat certification op schikkingsgedrag heeft, hoewel voorstanders ook wel wijzen op de proceseconomische voordelen van een vroegtijdige deugdelijkheidstoets. ${ }^{79}$

Zo wordt vaak betoogd dat een deugdelijkheidstoetsing in de preliminaire fase onwenselijke schikkingsdruk voorkomt. ${ }^{80}$ Een in literatuur en rechtspraak veelgehoorde bewering is dat het enkele certificeren van een class action - los van de uiteindelijke kans van slagen on the merits - al een grote druk op de verweerder legt om de zaak te schikken, vanwege de omvang van het procesrisico en de potentiële proceskosten. ${ }^{81}$ De dreiging die uitgaat van punitive damages speelt daarbij soms ook een rol. Een super-weak rule stelt de rechter in staat om (de meest) dubieuze claims in de preliminaire fase eruit te zeven, waardoor ze ook niet als pressiemiddel kunnen worden gebruikt. $^{82}$

Super-weak rules zouden daarnaast bijdragen aan de totstandkoming van 'geïnformeerde' schikkingen. ${ }^{83}$ Als de rechter ter gelegenheid van de certification een gemotiveerde voorlopige inschatting geeft van de kansen op succes, zullen partijen die informatie meewegen bij het uitonderhandelen van een schikking. Dat zou tot billijker uitkomsten leiden, omdat de uitkeringen die aan benadeelden worden toegekend dan beter zouden reflecteren wat hun 'verwachte opbrengst' uit de procedure zou zijn. Dit kan voorkomen dat advocaten aan eisers zijde sterke claims te goedkoop schikken en daardoor de benadeelden tekortdoen, maar ook dat zwakke claims voor een onevenredig hoog bedrag worden geschikt. ${ }^{84}$

77. Vgl. Miller 2004, p. 64. De Supreme Court heeft in Amgen, 133 S.Ct. 1184 (2013), op p. 1194-1195, bovendien nog eens ondubbelzinnig bevestigd dat eventuele merits inquiries zich moeten beperken tot wat relevant is voor certification.

78. Zie o.m. S.B. Berry, 'Ending substance's indenture to procedure: The imperative for comprehensive revision of the class damage action', Columbia Law Review (80) 1980, afl. 2, p. 312-315 e.v.; Towns 1992, p. 1001 e.v.; McGuire, 168 F.R.d. 366 (1996); G.L. Priest, 'Procedural versus substantive controls of mass tort class actions', The Journal of Legal Studies (26) 1997, p. 573; Bone \& Evans 2002, p. 1251 e.v.

79. Bijv. Dolgow, 43 F.R.D. 472 (E.D.N.Y. 1968), op p. 502; Rutherglen 1980, p. 731; McGuire, 168 F.R.d. 366 (1996), op p. 374-375.

80. Bone \& Evans 2002, p. 1255; McGuire, 168 F.R.d. 366 (1996), op p. 370-372 en 374-375; Towns 1992, p. 1011 en 1029-1032 (die in dit verband tevens ingaat op het nadeel van een afzonderlijke, van de certification losgekoppelde summary judgment-stap); Dolgow v. Anderson, 43 F.R.D. 472 (E.D.N.Y. 1968), op p. 502.

81. Bijv. Coopers \& Lybrand v. Livesay, 437 U.S. 463 (1978), op p. 476; In re Agent Orange Product Liability Litigation, 818 F.2d 145 (2nd Cir. 1987), op p. 151; McGuire, 168 F.R.d. 366 (1996), op p. 370-372.

82. Zie voor kritiek op dit argument echter Olson 2009, p. 966-975; Miller 2004, p. 78 e.v.

83. G.C. Hazard, 'Class certification based on the merits of the claims', Tennessee Law Review (69) 2001, p. 1-12.

84. McGuire, 168 F.R.d. 366 (1996), op p. 372-374. 
Mij dunkt kan daaraan worden toegevoegd dat de inzichten uit het preliminaire inhoudelijke onderzoek de rechter later kunnen helpen bij de beoordeling of een eventuele schikking 'fair, reasonable, and adequate' is..$^{85}$

Bezwaren tegen de vrije leer zijn er ook. Zo is aangevoerd dat ze certification omslachtig maakt en de drempel voor het entameren van een class action te zeer verhoogt. ${ }^{86}$ Daarnaast werd in Eisen de zorg geuit dat een voorlopig deugdelijkheidsoordeel de latere inhoudelijke behandeling zou kleuren, maar niet met de gebruikelijke procedurele waarborgen is omgeven. ${ }^{87}$ De gedachte is kennelijk dat de rechter in de preliminaire fase mogelijk op basis van ontoereikende informatie beslist, daardoor op het verkeerde been wordt gezet en vervolgens niet meer onbevangen naar de zaak kan kijken. Verschillende commentatoren menen overigens dat dit risico - hoewel niet denkbeeldig - genuanceerd moet worden, omdat in toereikende waarborgen kan worden voorzien. Zo zouden de reguliere bewijsregels op certification van toepassing kunnen worden verklaard, en wordt het in de context van een summary judgment ook niet bezwaarlijk geacht dat de rechter op basis van een meer beperkt partijdebat beslist. ${ }^{88}$ Ten slotte kunnen super-weak rules aanleiding geven tot strategisch optoutgedrag. ${ }^{89}$ Een voorlopig deugdelijkheidsoordeel betekent immers dat de rechter bij certification zijn eerste inschatting van de goede of slechte kansen van de zaak prijsgeeft. Als de rechter de kansen somber inschat (maar niet dusdanig somber dat certification uitblijft), dan valt een toename van het aantal opt-outs te verwachten als benadeelden de bui van tevoren zien hangen en binding aan een ongunstige uitspraak willen vermijden. Dat kan de finaliteit van de procedure ondergraven.

\section{Aanbevelingen voor de Nederlandse collectieve actie}

\subsection{Inleiding}

In de Verenigde Staten heeft de vraag hoe streng het verbod op een 'preliminary inquiry into the merits' zou moeten zijn de gemoederen lang beziggehouden, totdat de Supreme Court in 2011 helderheid verschafte. Diezelfde vraag - hoe scherp is de tweedeling tussen ontvankelijkheidsfase en inhoudelijke fase? - dringt zich nu ook in Nederland op in verband met het voorschrift van art. 1018c lid 5 Rv. De Amerikaanse discussie laat zien dat men daar op verschillende manieren mee om kan gaan, en kan inspiratie bieden bij het uitzetten van een koers in Nederland. Ik bespreek achtereenvolgens wat mijns inziens

85. Zie Rule 23(e)(2) FRCP.

86. Mersay v. First Republic Corporation of America, 43 F.R.D. 465 (S.D.N.Y. 1968), op p. 469. Vgl. voorts Olson 2009, p. 935-978; Davis \& Cramer 2009, p. 355-402; Osefchen \& Fuoco 2011, p. 59-76; M.J. Kaufman \& J.M. Wunderlich, 'The unjustified creation of class certification merits trials in securities fraud class actions', University of Michigan Journal of Law Reform (43) 2010, afl. 2, p. 323.

87. Eisen, 417 U.S. 154 (1974), op p. 177-178.

88. Towns 1992, p. 1019 (voetnoot 121). Zie ook McGuire, 168 F.R.d. 366 (1996), op p. 402-403; Miller 2004, p. 68.

89. Miller 2004, p. 69-77. Zie ook Rutherglen 1980, p. 735; Marcus 2011, p. 332-333. de relevantie hiervan is voor de omgang met de Nederlandse gelijksoortigheidseis (par. 5.2) en summiere ondeugdelijkheidstoets (par. 5.3).

\subsection{De gelijksoortigheidseis}

In het kader van de gelijksoortigheidstoets beoordeelt de rechter in hoeverre de in de collectieve rechtsvordering verdisconteerde individuele vorderingsrechten van benadeelden zich voor een gemeenschappelijke beoordeling lenen. Mede op basis daarvan moet hij vervolgens bepalen of een collectieve actie efficiënter en effectiever is dan alternatieven als individuele procedures of claimbundeling op basis van lastgeving of cessie (art. 3:305a lid 1 jo. art. 1018c lid 5 onder a en b Rv). Het onderzoek dat hij in dit kader verricht, is voorts medebepalend voor de afbakening van de nauw omschreven groep personen in de zin van art. 1018 e lid $2 \mathrm{Rv} .{ }^{90}$

Ik betoogde hiervoor (par. 3.2) dat de gemeenschappelijkheidsbeoordeling voldoende zicht vereist op zowel de juridische en feitelijke grondslagen van de vordering als de juridische en feitelijke grondslagen van het daartegen gerichte verweer. Het lijkt mij daarom onwenselijk dat verweerders met een beroep op art. $1018 \mathrm{c}$ lid 5, laatste volzin, $\mathrm{Rv}$ de kaarten volledig tegen de borst houden. Een verweerder die dit wel doet, dient rekening te houden met de mogelijkheid dat de rechter de ontvankelijkheidsvragen uitsluitend op basis van de stellingen van de eiser zal beoordelen.

Ik meen dat het nog een stap verder kan en dat een meer genuanceerde lezing van art. 1018c lid 5, laatste volzin, Rv op zijn plaats is. Immers, niet alleen het belang van de verweerder is gemoeid met een juiste inschatting van de haalbaarheid van de collectieve actie. Het is ook van betekenis voor de belangenorganisatie, de benadeelden en voor een efficiënte inzet van schaarse rechtspraakcapaciteit. Een redelijke uitleg van art. 1018c lid 5, laatste volzin, Rv brengt daarom mijns inziens mee dat de verweerder zijn inhoudelijke verweer in de preliminaire fase reeds op hoofdlijnen uiteen moet zetten, voor zover dat nodig is om de rechter in staat te stellen een geïnformeerde (ambtshalve) beslissing te nemen over deze

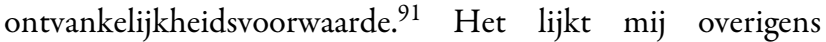
aannemelijk dat veel verweerders dat toch al uit eigen beweging zouden doen, teneinde te betwisten dat aan het gelijksoortigheidsvereiste is voldaan. Laat een verweerder dat achterwege, dan kan de rechter naar analogie van art. $21 \mathrm{Rv}$ de gevolgtrekking maken die hij geraden acht. Denkbaar is bijvoorbeeld een sanctie als verval van het recht om onvol-

90. Vgl. Kamerstukken II 2016/17, 34608, nr. 3, p. 41.

91. De toelichting biedt mogelijk een aanknopingspunt voor die lezing in de opmerkingen dat het 'onwenselijk is dat de bele inhoudelijke behandeling plaatsvindt' voordat de rechter over de ontvankelijkheid beslist, en dat voorkomen wordt dat de verweerder kosten makkt voor een 'uitvoerig inhoudelijk verweer'. Hoewel de tekst van art. 1018c lid 5 Rv een scherpe scheiding tussen ontvankelijkheidsfase en inhoudelijke behandeling suggereert, kan in die opmerkingen wellicht een nuancering worden gelezen. Zie Kamerstukken II 2016/17, 34608, nr. 3, p. 39-40 (cursief toegevoegd). 
doende 'aangekondigde' verweren in de inhoudelijke fase (alsnog) te voeren. ${ }^{92}$

Vervolgens is de vraag hoe de rechter in dit verband de inhoudelijke stellingen van partijen moet benaderen. Ik ben geneigd om een variant op de Amerikaanse strong-form rules (de strenge leer), waarbij de rechter niet voorbij de stellingen van partijen mag kijken, als te rigide van de hand te wijzen. Een dergelijke benadering houdt weliswaar het inhoudelijke debat in de preliminaire fase compact, maar kan ertoe leiden dat de rechter genoodzaakt is om twijfel over de mogelijkheden van een collectieve beoordeling en over de juiste afbakening van de nauw omschreven groep voor zich uit te schuiven.

Ik denk daarom dat er meer valt te zeggen voor een benadering die lijkt op de door de Amerikaanse rechtspraak omarmde weak-form rules (de gematigde leer). Dit zou voor Nederland betekenen dat de rechter zich in de eerste fase niet per definitie hoeft te beperken tot een beoordeling aan de hand van de stellingen van partijen, maar ook een voorlopige beslissing mag geven - eventueel na bewijslevering - over inhoudelijke geschilpunten die relevant zijn voor de beoordeling van de gelijksoortigheid. Men kan bijvoorbeeld denken aan de inroepbaarheid van een cruciaal causaliteitsvermoeden, of een feitelijk geschil over de vraag of een verweerder uniforme dan wel per geval verschillende mededelingen aan gedupeerden heeft gedaan. Het gaat dus om een gericht, 'chirurgisch' inhoudelijk onderzoek. Of de rechter daartoe overgaat, is afhankelijk van de omstandigheden van het geval. Daarbij kan hij het belang van een voorspoedige en efficiënte procesvoering in de preliminaire fase telkens afwegen tegen de noden van een grondige gelijksoortigheidstoets. Het ligt voor de hand dat de rechter in ieder geval zo'n voorlopig oordeel velt indien beide partijen daarom vragen, maar mijns inziens kan hij, als de zaak er aanleiding toe geeft, ook op verzoek van één partij of uit eigen beweging daartoe overgaan.

Ter illustratie contrasteer ik deze benadering met een recent voorbeeld uit de rechtspraak onder het oude collectieve-actieregime, waarin de rechter - wellicht met de WAMCA in gedachten - een separaat vonnis over de ontvankelijkheid wijst. In een collectieve actie tegen fabrikanten en verkopers van 'sjoemeldiesels' werd door Stichting Volkswagen Car Claim (onder meer) een collectief beroep op dwaling gedaan. ${ }^{93}$ Dat beroep berustte op de stelling dat de betrokken auto's niet aan de toepasselijke wet- en regelgeving voldoen en dat dit een zo essentiële eigenschap is dat geen weldenkende koper bij een juiste voorstelling van zaken een koopovereenkomst zou zijn aangegaan. Om die reden zou volgens Car Claim geen beoordeling van individuele omstandigheden rondom de wilsvorming van gedupeerden meer nodig zijn, zodat de rechter daarover in een collectieve actie kan oordelen. Een en ander werd door Volkswagen c.s. bestreden. De recht-

92. Voor de goede orde: vanzelfsprekend geldt voor de eiser eveneens dat hij de gronden van zijn rechtsvordering en zijn strategie voor het leveren van het vereiste 'collectief bewijs' in de ontvankelijkheidsfase voldoende uiteen moet zetten, aangezien de rechter de gelijksoortigheid zal moeten beoordelen in het licht van de standpunten van beide partijen (par. 3.2).

93. Rb. Amsterdam 20 november 2019, ECLI:NL:RBAMS:2019:8741 (Volkswagen Car Claim), i.h.b. r.o. 6.5-6.8. bank vond de redenering van Car Claim echter niet op voorhand uitgesloten en achtte de dwalingsvordering ontvankelijk, maar ging verder niet inhoudelijk op de stellingen van partijen in. Of die redenering inderdaad zal opgaan, blijft derhalve een open vraag die pas bij inhoudelijke behandeling aan de orde zal komen. Bij de benadering die ik hiervoor schetste, zou de rechter de vraag of een dergelijke 'geen weldenkende koper'redenering opgaat wel (voorlopig) beantwoorden in de voorfase, omdat bij een ontkennend antwoord de waarschijnlijke conclusie is dat de dwalingsvordering zich niet voor gemeenschappelijke beoordeling leent. Dan is in zoverre niet aan het gelijksoortigheidsvereiste voldaan, zodat de betreffende vordering niet-ontvankelijk is. ${ }^{94}$

Een tweede voorbeeld kan worden ontleend aan het vonnis in een collectieve actie van de beroepsorganisatie van tandartsen KNMT tegen Buma, dat ook onder het oude regime is gewezen. ${ }^{95}$ Inzet van die zaak waren de licentievergoedingen die Buma int van de tandheelkundige praktijken die KNMT vertegenwoordigt voor de achtergrondmuziek die ze in hun wachtruimte draaien. KNMT vorderde in deze procedure (onder meer) een verklaring voor recht dat de tandartspraktijken geen vergoedingen verschuldigd zijn, omdat dit gebruik geen 'mededeling aan het publiek' zou behelzen volgens de jurisprudentie van het Hof van Justitie. Buma voerde in het kader van de ontvankelijkheid aan dat de vorderingen zich niet voor collectieve behandeling lenen. Anders dan KNMT betoogde, volgde volgens Buma uit die rechtspraak geen algemene regel, maar juist dat steeds een geïndividualiseerde beoordeling nodig is. De rechtbank overwoog echter dat Buma met haar argument ter zake in feite [vooruitloopt] op de inhoudelijke discussie omtrent het begrip "mededeling aan het publiek"'. Ze ging bij de beoordeling van de gelijksoortigheid niet op dat betoog in en achtte KNMT ontvankelijk. Bij de inhoudelijke behandeling van de rechtsvordering moest de rechtbank echter alsnog concluderen dat de vaststelling dat een tandheelkundige praktijk geen mededeling aan het publiek doet een individuele beoordeling vergt, waardoor het niet mogelijk was de gevorderde collectieve verklaring voor recht te geven. KNMT had ook geen feiten en omstandigheden aangevoerd die een (meer) individuele beoordeling mogelijk maakten.

Achteraf bezien had de rechtbank onder die omstandigheden, meen ik, moeten oordelen dat aan de gelijksoortigheidseis niet was voldaan. Zou deze gang van zaken onder het nieuwe WAMCA-regime worden herhaald, dan zou na een foutpositieve preliminaire ontvankelijkheidsbeslissing vermoedelijk pas bij de inhoudelijke behandeling van de vordering blijken dat de zaak zich niet voor een collectieve actie leent. Voordat men tot dat inzicht komt, is mogelijk reeds een exclusieve belangenbehartiger benoemd (art. 1018e $\mathrm{Rv}$ ), een potentieel kostbare opt-outkennisgeving uitgegaan

94. Zie voor een soortgelijk voorbeeld waarin de rechter om die reden een collectief dwalingsberoep niet-ontvankelijk acht Rb. Oost-Brabant 29 juni 2016, ECLI:NL:RBOBR:2016:3383, r.o. 5.33.

95. Rb. Amsterdam 24 juli 2019, ECLI:NL:RBAMS:2019:5392 (KNMT) Buma), i.h.b. r.o. 4.5-4.7 en 4.26-4.30. 
(art. 1018f Rv), zijn de daaropvolgend binnengekomen optoutverklaringen verwerkt, en hebben partijen kosten gemaakt voor hun verdere procesvoorbereiding. Dat kan worden voorkomen als de rechter in het kader van de ontvankelijkheidstoets een voorlopig oordeel geeft over dit voor de haalbaarheid van een collectieve beoordeling relevante inhoudelijke discussiepunt.

Een benadering zoals hier bepleit lijkt mij ook verenigbaar met de strekking en ratio van art. 1018c lid 5 Rv. Daadwerkelijke inhoudelijke behandeling van de vordering vindt immers nog steeds pas na de preliminaire ontvankelijkheidsbeslissing plaats, nu (1) in de voorfase alleen inhoudelijke vragen worden behandeld die van directe betekenis zijn voor de gelijksoortigheidsbeslissing en de afbakening van de nauw omschreven groep, en (2) de beslissingen die de rechter in dat verband neemt een voorlopig karakter hebben en in de inhoudelijke fase opnieuw ter discussie (kunnen) staan. Indien effectief toegepast, is het bovendien in lijn met de efficiency-gedachte die aan de procedurele tweedeling ten grondslag ligt. Het kan de rechter immers beter in staat stellen om te beoordelen of en in hoeverre de zaak zich voor een collectieve actie leent, wat de kans op 'missers' (zie par. 2) kan verkleinen. Een steviger inhoudelijk debat in de voorfase kan daarnaast voor eisers aanleiding vormen om de formulering van de eis aan te scherpen, omdat eventuele knelpunten in de opzet van de massaclaim in een vroeg stadium worden blootgelegd.

\subsection{De summiere ondeugdelijkheidstoets}

De summiere ondeugdelijkheidstoets (art. 1018c lid 5 onder c $\mathrm{Rv}$ ) biedt een grondslag om in uitzonderlijke gevallen een collectieve rechtsvordering vroegtijdig af te wijzen, als aanstonds al blijkt dat ze "niet deugt. ${ }^{96}$ Die afwijzing kan kennelijk ook op inhoudelijke gronden zijn gebaseerd (par. 3.3). Het Nederlandse recht bevat aldus een vorm van inhoudelijke deugdelijkheidstoetsing in de eerste fase van de collectieve procedure, zoals ook in de Amerikaanse literatuur door aanhangers van de vrije leer is bepleit als onderdeel van de certification-beslissing (zie par. 4.4 onder $\mathrm{c}$ ).

De Nederlandse toets is echter van minder vergaande strekking dan de figuur die in de Verenigde Staten veelal wordt verdedigd. De toets in de WAMCA is in de woorden van de wetgever bedoeld voor de uitzonderingsgevallen. De rechter toetst slechts of summierlijk van de ondeugdelijkheid blijkt. Dat inhoudelijke onderzoek is dus van beperkte omvang en is erop gericht om vast te stellen dat de collectieve vordering nimmer tot toewijzing kan leiden. Pleitbezorgers van super-weak rules in de Amerikaanse literatuur plegen een grotere rol aan de deugdelijkheidstoets toe te kennen, waar zij een voldoende kans op toewijzing als een positieve voorwaarde voor certificering poneren. Die vraag zou zodoende voor elke collectieve vordering moeten worden beantwoord door middel van een integrale voorlopige beoordeling van de zaak, en dus niet slechts wanneer evidente gebreken in haar onderbouwing daartoe aanleiding geven. De belangrijkste

96. Kamerstukken II 2016/17, 34608, nr. 3, p. 39 argumenten die voorstanders in de Verenigde Staten voor die benadering aandragen, is dat ze oneigenlijke schikkingsdruk voorkomt en verder bijdraagt aan de totstandkoming van schikkingen die recht doen aan de inhoudelijke merites van de zaak.

Ik zie vooralsnog geen reden om de Nederlandse summiere ondeugdelijkheidstoets te (her)modelleren naar de in de Amerikaanse literatuur bepleite ruime deugdelijkheidstoets, voor zover dat al mogelijk zou zijn binnen de huidige, terughoudende formulering van art. 1018c lid 5 onder c Rv. Daartegen pleit immers dat een ruime inhoudelijke toets uitnodigt tot een uitvoerig inhoudelijk debat in de preliminaire fase - veel meer dan het geval is bij de gerichte behandeling van slechts de voor het gelijksoortigheidsoordeel van belang zijnde inhoudelijke vragen, die ik hiervoor omschreef. Het leidt potentieel tot een aanzienlijke verzwaring van de procesvoering in de preliminaire fase. Verder werpt een 'voldoende kans van slagen'standaard voor eisers een bedenkelijke extra drempel op om een collectieve actie aan te brengen. Een vordering die op basis van een beperkt partijdebat in de preliminaire fase kansarm voorkomt, is immers niet per definitie kansloos. Het is goed mogelijk dat verdere ontwikkeling van het partijdebat de zaak in een ander licht plaatst. Als het uitgangspunt voor de Nederlandse regeling blijft dat alleen een klaarblijkelijk ongegronde vordering vóór de inhoudelijke behandeling kan worden afgewezen, lijkt het mij intussen onwaarschijnlijk dat een meer uitvoerig (niet-summier) preliminair ondeugdelijkheidsonderzoek leidt tot een meer effectieve schifting. Als een vordering niet aanstonds evident ongegrond blijkt, zal de rechter vermoedelijk, ook na een meer uitgebreid vooronderzoek, in veel gevallen hooguit kunnen constateren dat de zaak kansarm is, doch niet kennelijk ongegrond. Dan is de slotsom nog steeds dat de zaak door kan en moet naar de inhoudelijke fase.

De voornaamste argumenten die in de Amerikaanse literatuur voor een ruime deugdelijkheidstoets zijn aangedragen, houden bovendien sterk verband met de bijzonderheden van de Amerikaanse collectieve schikkingspraktijk. Factoren als de mogelijkheid van punitive damages, de tijd en moeite die met de discovery-fase zijn gemoeid en de hoge proceskosten, die partijen in principe zelf dragen, maken procederen relatief onaantrekkelijk. Het is daardoor de vraag in hoeverre die argumenten zich naar de Nederlandse situatie laten vertalen. Dat oneigenlijke schikkingsdruk in Nederland een reëel probleem vormt, is niet aangetoond (en overigens zijn er ook in de Verenigde Staten wel twijfels bij geplaatst). ${ }^{97}$ Verder heeft de rechter in het Nederlandse systeem voldoende mogelijkheden om na de preliminaire fase van de procedure partijen desge-

97. Vgl. Tzankova 2017, p. 108 e.v. Kritiek op het in de VS vaak aangevoerde maar zelden onderbouwde gevaar van 'blackmail settlements' vindt men bijv. in C. Silver, 'We're scared to death: Class certification and blackmail', New York University Law Review (78) 2003, afl. 4, p. 1357-1430; A. Kanner \& T. Nagy, 'Exploding the blackmail myth: A new perspective on class action settlements', Baylor Law Review (57) 2005, afl. 3, p. 681-704; B. Hay \& D. Rosenberg, 'Sweetheart and blackmail settlements in class actions: Reality and remedy', Notre Dame Law Review (75) 2000, afl. 4, p. 1377-1408. 
wenst een voorlopig oordeel te geven over bepaalde kwesties die hen verdeeld houden, bijvoorbeeld door een comparitie te houden, alvorens partijen de in art. $1018 \mathrm{~g}$ Rv bedoelde gelegenheid te geven om een schikking te beproeven. ${ }^{98}$ Ook zonder verruiming van de preliminaire (on)deugdelijkheidstoets kan de rechter zodoende behulpzaam zijn bij het bereiken van een schikking. Bijkomend voordeel is dat, zo men strategisch opt-outgedrag zou wensen te voorkomen, de rechter daarmee kan wachten tot na het verstrijken van de opt-outtermijn (art. 1018f Rv).

\section{Conclusie}

Hoewel de wet de scheidslijn tussen ontvankelijkheidstoets en inhoudelijke behandeling scherp voorstelt, is het niet goed mogelijk om de twee volledig uit elkaar te trekken. De 'inhoudelijke' elementen van die toets in de vorm van de gelijksoortigheidseis en de summiere ondeugdelijkheidstoets nemen elk op hun eigen manier een voorschot op de inhoudelijke behandeling. Dat heeft de potentie om via een omweg alsnog meer of minder uitvoerige inhoudelijke discussies in de voorfase binnen te laten, wat afbreuk kan doen aan de efficiencygedachte achter de procedurele tweesplitsing. Anderzijds kan men die discussies ook weer niet geheel uit de weg gaan zonder de ontvankelijkheidstoets uit te hollen. Slaagt de rechter er daardoor onvoldoende in om het kaf van het koren te scheiden, dan kan ook dat leiden tot inefficiënte procesvoering (bij een foutpositieve beslissing) of zelfs een onterecht voortijdig einde aan de zaak (bij een foutnegatieve beslissing). Het is dus zoeken naar een evenwicht. Ervaringen in de Verenigde Staten, waar in het kader van de federale class action-procedure ook de vraag is gerezen in hoeverre er ruimte moet zijn voor inhoudelijk onderzoek in de ontvankelijkheidsfase (certification), kunnen inspiratie bieden bij het uitzetten van een koers in Nederland.

Een redelijke uitleg van art. 1018c lid 5, laatste volzin, Rv brengt mijns inziens mee dat de verweerder zijn inhoudelijke verweer in de preliminaire fase reeds op hoofdlijnen uiteen moet zetten, voor zover dat nodig is om de rechter in staat te stellen een geïnformeerde (ambtshalve) beslissing te nemen over het gelijksoortigheidsvereiste. Verder lijkt het mij met de strekking en de ratio van art. 1018c lid $5 \mathrm{Rv}$ verenigbaar en bovendien met het oog op een degelijke toetsing van de gelijksoortigheid wenselijk dat de rechter in voorkomende gevallen reeds in de preliminaire fase een voorlopige beslissing geeft - eventueel na bewijslevering - over voor die beoordeling relevante inhoudelijke geschilpunten. Een uitvoerig inhoudelijk debat in het kader van de summiere ondeugdelijkheidstoets lijkt mij bij de huidige stand van zaken echter niet opportuun. 